\title{
THE CONFLICT OF LAWS IN ADMINISTRATION OF EXPRESS TRUSTS OF PERSONAL PROPERTY
}

\author{
WALTER W. SWABENLAND $\dagger$
}

\section{INTRODUCTION}

THE rapid growth of trusts in this century coupled with a mobile society and economy has created numerous situations in which the elements of the trust are divided between two or more states. This division of elements raises with increasing frequency the problem as to what law governs the administration ${ }^{1}$ of express ${ }^{2}$ trusts of personalty ${ }^{3}$ created either by will or deed.

A preliminary question of jurisdiction presents itself, as to what court will pass upon questions arising in the administration of a trust. The cases involving jurisdiction fall into the following three groups: (1) voluntary proceedings by the trustee, as proceedings to account or for instructions; (2) proceedings against a trustee by some third person where no question of the trustee's dishonesty is involved; and (3) proceedings against a dishonest trustee who is misappropriating and dissipating the trust assets.

In a voluntary proceeding by the trustee the cases indicate that the petition should be filed in the court which admitted the will to probate, which normally would be at the domicil of the testator. ${ }^{4}$ If, however, the trust was created by an inter vivos gift, the few existing cases indicate

$\dagger$ Member of the New York Bar.

1. It is often difficult to determine at what point the creation aspects of a trust end and the administration aspects begin. In the present article a simple rule has been followed of treating only those problems which arise after the title to the trust property has duly passed to the trustee and he has begun his labors.

That the validity of a testamentary trust of personalty is governed by the law of the testator's domicil at the time of his death seems to be well established. Beale, Equitable Interests in Foreign Property (1907) 20 HaRv. L. REv. 382. An exception to this general rule must be made in certain instances, as, for example, in the case of a bequest to a charity located in a foreign state or country. Comment (1932) 32 Cor. L. REv. 680.

Contrasted to both validity and administration of a trust is the matter of construction or interpretation of the trust instrument. Generally the same law governs the construction as governs the validity of a trust.

2. Only express trusts are considered in this article. Likewise, the present discussion will be limited to family settlement trusts and will not deal with conflict of law problems arising in business insurance trusts, investment trusts, trusts under corporate mortgages, community trusts, etc.

3. Trusts of real property will not be considered herein, since the rule seems firmly established that all matters relating to land, including trusts, are governed by the law of the situs of the land.

4. Marsh v. Marsh's Ex'rs., 73 N. J. Eq. 99, 67 Atl. 706 (Ch. 1907); M'Cullough's Ex'rs. v. M'Cullough, 44 N. J. Eq. 313, 14 Atl. 642 (Ch. 1888); see Swetland v. Swetland, 105 N. J. Eq. 608, 149 Atl. 50 (Ch. 1930). 
that the trustee should turn to the courts of the state in which the numerical preponderance of the following facts existed: (a) domicil of the settlor at the time of the creation of the trust; (b) domicil of the trustee; (c) place of execution of the deed of trust; and (d) location of the trust property. ${ }^{5}$

In suits brought against a trustee by some third person where no question as to the trustee's honesty is involved, the state of probate, as in the previous instance, will exercise jurisdiction. ${ }^{\circ}$ In addition, courts of other states generally assume jurisdiction if the trustee resides in the forum state and the trust property is wholly or in part within that state. ${ }^{7}$ If, however, a proceeding is pending in the probate state, a court of another state will generally refuse to exercise jurisdiction over the trust ${ }^{\mathrm{g}}$ unless the parties to the earlier proceeding consent to abandon it. ${ }^{\circ}$ When a living trust is involved in such a suit, little authority in regard to the jurisdiction of courts exists. In one instance ${ }^{10}$ in which the deed of trust was executed in Massachusetts, all of the interested parties were residents of Massachusetts, and the property was located therein, a New York court held that jurisdiction should be exercised by Massachusetts courts. ${ }^{11}$ This decision is hardly an adequate basis for formulating a rule which will predict the future course of the courts with any precision. But since the subject of the actions brought in this instance are on the whole similar to those brought by a trustee to account or for instructions, the rule in this analagous situation will probably be followed.

Jurisdiction in actions against dishonest trustees will be exercised by

5. Russell v. Joys, 227 Mass. 263, 116 N. E. 549 (1917); Greenough v. Ozgood, 235 Mass. 235, 126 N. E. 461 (1920). In the event the four factors listed were evenly divided between two states the court would probably consider additional factors.

6. Matter of Avery, 45 Misc. 529, 92 N. Y. Supp. 974 (Surr. Ct. 1904); Chase v. Chase, 2 Allen 101 (Mass. 1861).

7. Hussey v. Sargent, $116 \mathrm{Ky}, 53,75 \mathrm{~S}$. W. 211 (1903); Farmers' Loan and Trust Co. v. Pendleton, 37 Misc. 256, 75 N. Y. Supp. 294 (Sup. Ct. 1902); Braman v. Braman, 236 App. Div. 164, 258 N. Y. Supp. 181 (1st Dep't, 1932). Contra: Jenkins v. Lester, 131 Mins. 355 (1881); Leland v. Smith, id. at 358 (1881). It has been held in Jones v. Jones, 8 Misc. 660, 30 N. Y. Supp. 177 (Sup. Ct. 1894) that even where the trust property was in the state of the domicil of the testator and probate of the will and only the trustees were in the forum state, jurisdiction would still be exercised by the forum. If, however, a trust company of the state of the domicil of the testator and probate of the will is the trustee, and subjects itself to jurisdiction in the forum by doing business there, the court of the forum will refuse to exercise jurisdiction. Everhart v. Provident Life and Trust Company, 118 Misc. 852, 195 N. Y. Supp. 388 (Sup. Ct. 1922).

8. Schuster v. Superior Court, 98 Cal. App. 619, 277 Pac. 509 (1929).

9. Marsh v. Marsh's Ex'rs., 73 N. J. Eq. 99, 67 Atl. 706 (Ch. 1907). No cres whs found of a situation in which an attempt was made to bring an action in the probate state when one was already pending in some other state.

10. In re Berry, 178 App. Div. 144, 164 N. Y. Supp. 990 (1st Dep't, 1917).

11. In Jenkins v. Lester, 131 Miass. 355 (1881) there is a dictum to the effect that if the trustee of a living trust and the trust property were in one state, the courts of that state would exercise jurisdiction over an action against a trustee. 
the court of any state in which the trustee can be served with process or part of the trust property is located, regardless of how the trust was created. ${ }^{12}$

After a court has decided to exercise jurisdiction in the administration -of a trust, it must then determine in conflicts of law cases whether the law of its own state or the law of some other state shall govern the determination of the cause. We turn, then, to a consideration of the problem of choice of law.

\section{What Law Governs Administration of the Trust}

Problems of administration include such matters as the investment of trust funds, the amount of trustee's commissions, the adjustments to be made between income and principal and similar questions. ${ }^{13}$ Various rules have been suggested for determining which state's law is applicable to these questions. The American Law Institute has formulated the following rule for testamentary trusts:

Section 298. "A testamentary trust of movables is administered by the trustee according to the law of the state of the testator's domicil at the time of his death unless the will shows an intention that the trust should be administered in another state."

Comment c. "If the testator appoints as trustee a trust company of another state, presumably his intention is that the trust should be administered in the latter state; the trust will, therefore, be administered according to the law of the latter state."14

To properly test this rule cases should be found in which the domicil of the testator stands alone in one state and a preponderance of the remaining factors are located in another state. If the Restatement rule is accurate, these decisions will be found to follow the law of the testator's domicil. Similarly, to adequately test the exception to the rule, found in comment $c$, cases should be found in which a trust company domiciled in one state is designated as trustee and a preponderance of the remaining elements of the trust are in another state. Here again, if the Restatement rule is well founded, the law of the trustee's domicil will be found to govern.

The American Law Institute ${ }^{15}$ has formulated the following rule for trusts:

12. Whitney v. Dodge, 105 Cal. 192, 38 Pac. 636 (1894); Squier v. Houghton, 131 Misc. 129, 226 N. Y. Supp. 162 (Sup. Ct. 1927) ; Swetland v. Swetland, 105 N. J. Eq. 608, 149 Atl. 50 (Ch. 1930).

13. Other administration matters which have raised the question of the governing law are the alienability of the beneficiary's interest or creditors' rights against the beneficiary, actions to terminate the trust, and actions to remove the trustee.

14. Restatement, Conflict of Laws (1934) §298.

15. Restatement, op. cit. supra note $14, \S 297$. 
Section 297. "A trust of movables created by an instrument inter vivos is administered by the trustee according to the law of the state where the instrument creating the trust locates the administration of the trust."

Comment $d$. "In order to determine where the administration of the trust is located, consideration is given to the provisions of the instrument, the residence of the trustees, the residence of the beneficiaries, the location of the property, the place where the business of the trust is to be carried on."

Several other rules also have been laid down for determining the governing law in the administration of trusts of personality. Cook states that the administration of a testamentary trust should be goverened by the law of the jurisdiction with which "the trust has the most substantial connection."10 Approacining in similar manner the problem of administration of living trusts of personalty, Beale expressed the view that the law of the "situs or seat of the trust" should govern, and that the situs is determined by an interpretation of the words by which the trust is created and all indications are considered, as the intention of the parties, the place of business or domicil of the trustee, the location of the trust res, and other similar matters. ${ }^{17}$

A practitioner faced with the problem of advising a trustee as to what law he should look to in administering a trust which has elements in two or more states receives but little guidance from these rules. Cook gives no suggestions as to how one is to determine which is the place of "most substantial connection" of a testamentary trust. Beale lists only four factors as being important in determining the situs of an inter vivos trust, although he indicates there are others. Moreover, he gives no explanation of the sense in which "intention of the parties" is used. Nor do the above rules, excepting the Institute's rule in regard to testamentary trusts, help the practitioner in determining whether more consideration is given by the courts to certain factual connections than to others. One might well assume from reading the rules formulated by Beale and the American Law Institute for inter vivos trusts that a mere numerical preponderance of the factors in one state would cause the lav of that state to govern. Similarly no attempt has been made in the above rules to provide for the situation where the elements of the trust have shifted between the time the trust was created and the action arose. The attorney, as a practical matter, also would like to know, when drafting trust instruments, how far the express intention of the creator can determine the governing law. This article will attempt an examination of existing case law with the object of appraising the tests suggested

16. Comment (1919) 19 Cor. L. REv. 486. Cook discards the following rules: 3. The testator's domicil at death. b. The trustee's domicil. c. The domicil of the bencficiaries. d. The place where the trust is administered. e. The situs of the property.

17. Beale, Living Trusts of Mlovables in the Conflict of Larus (1932) 45 Husv. L. RE: 969; see also 2 BEALE, THE CONFLICT of LAws (1935) pp. 1023-1024; Beale, op. cit. stspra note 1 , at 395 . 
by the American Law Institute, and of suggesting answers to these problems which the Restatement and the treatise writers have left unanswered. ${ }^{18}$

In the absence of an express statement by the settlor as to which law is intended to govern, the courts have referred to and considered the following factors to determine the governing law:

1. The domicil of the creator of the trust. ${ }^{10}$

2. The place in which the trust deed was executed. ${ }^{20}$

3. The language of the trust instrument. ${ }^{21}$

4. The place of probate of the will. ${ }^{22}$

5. The location of the trust property. ${ }^{23}$

6. The domicil of the trustee. ${ }^{24}$

18. In the past, testamentary and inter vivos trusts have been treated separately and different rules have been formulated for determining the governing law of each. In this article all cases dealing with what law governs the administration of express trusts of personalty will be discussed together. It is believed that a more helpful analysis will thus be possible.

19. Matter of Avery, 45 Misc. 529, 92 N. Y. Supp. 974 (Surr. Ct. 1904); Allen v. Tate, 6 F. (2d) 139 (C. C. A. 8th, 1925); Farmers' and Mechanics' Bank v. Brewer, 27 Conn. 600 (1858); Lanius v. Fletcher, 100 Texas 550, 101 S. W. 1076 (1907); Lozier v. Lozier, 99 Ohio St. 254, 124 N. E. 167 (1919); Squier v. Houghton, 131 Misc. 129, 226 N. Y. Supp. 162 (Sup. Ct. 1927); Merritt v. Corties, 24 N. Y. Supp. 561 (Sup. Ct. 1893); Rosenbaum v. Garrett, 57 N. J. Eq. 186, 41 Atl. 252 (Ch. 1898) ; Russell v. Joys, 227 Mass. 263, 116 N. E. 549 (1917); Curtis v. Curtis, 185 App. Div. 391, 173 N. Y. Supp. 103 (1st Dep't, 1918); First National Bank of Paterson (N. J.) v. The National Broadway Bank in the City of New York, 156 N. Y. 459, 51 N. E. 398 (1898); Spooner v. Phillips, 62 Conn. 62, 24 Atl. 524 (1892); Mercer v. Buchanan, 132 Fed. 501 (C. C. W. D. Pa. 1904); and Swetland v. Swetland, 105 N. J. Eq. 608, 149 Atl. 50 (Ch. 1930).

20. Codman v. Krell, 152 Mass. 214, 25 N. E. 90 (1890); Mercer v. Buchanan, 132 Fed. 501 (C. C. W. D. Pa. 1904) ; First National Bank of Paterson (N. J.) v. The National Broadway Bank in the City of New York, 156 N. Y. 459, 51 N. E. 398 (1898); Curtis v. Curtis, 185 App. Div. 391, 173 N. Y. Supp. 103 (1st Dep't, 1918); In re Berry, 178 App. Div. 144, 164 N. Y. Supp. 990 (1st Dep't, 1917); In re Fitzgerald (1904), 1 Ch. 573 .

21. Townsend v. Allen, 13 N. Y. Supp. 73, aff'd, 126 N. Y. 646, 27 N. E. 853 (1891); Codman v. Krell, 152 Mass. 214, 25 N. E. 90 (1890); Greenough v. Osgood, 235 Mass, 235, 126 N. E. 461 (1920) ; Farmers' and Mechanics' Bank v. Brewer, 27 Conn, 600 (1858).

22. Suskin \& Berry v. Rumley, 37 F. (2d) 304 (C. C. A. 4th, 1930); Farmers' and Mechanics' Bank v. Brewer, 27 Conn. 600 (1858); Union \& New Haven Trust Company v. Watrous, 109 Conn. 268, 146 Atl. 727 (1929); Sale v. Saunders, 24 Miss. 24 (1852); Rosenbaum v. Garrett, 57 N. J. Eq. 186, 41 Atl. 252 (Ch. 1898); Matter of Avery, 45 Misc. 529, 92 N. Y. Supp. 974 (Surr. Ct. 1904); Lozier v. Lozier, 99 Ohio St. 254, 124 N. E. 167 (1919); Lanius v. Fletcher, 100 Texas 550, 101 S. W. 1076 (1907).

23. Allen v. Tate, 6 F. (2d) 139 (C. C. A. 8th, 1925); Suskin \& Berry v. Rumley, 37 F. (2d) 304 (C. C. A. 4th, 1930) ; Farmers' and Mechanics Bank v. Brewer, 27 Conn. 600 (1858); Greenough v. Osgood, 235 Mass. 235, 126 N. E. 461 (1920); Merritt v. Corties, 24 N. Y. Supp. 561 (Sup. Ct. 1893); Matter of Avery, 45 Misc. 529, 92 N. Y. Supp. 974 (Surr. Ct. 1904); Curtis v. Curtis, 185 App. Div. 391, 173 N. Y. Supp. 103 (1st Dep't, 1918); Lanius v. Fletcher, 100 Texas 550, 101 S. W. 1076 (1907); In re Fitzgerald (1904), $1 \mathrm{Ch}$. 573.

24. Mercer v. Buchanan, 132 Fed. 501 (C. C. W. D. Pa. 1904); Farmers' and Mechanics,. 
7. The domicil of the beneficiary. ${ }^{25}$

8. The place in which the business of the trust is carried on..$^{20}$

9. The intention of the creator. ${ }^{27}$

The first eight factors may be conveniently grouped according to the aspect of the trust which is involved. Thus, the first four factors relate to the creation of the trust; the fifth has to do with the property constituting the trust res; and the sixth, seventh and eighth deal with the performance of the trust.

An interesting question is presented as to whether the forum of the action is a factor considered by the court in its determination of what law governs. Only one case ${ }^{28}$ was found in which this factor was expressly referred to by a court; and since there is no evidence that it is generally considered, it is not listed in this article as being influential. The court, however, may be inclined to apply its local law without being conscious of its tendency to do so, particularly if no one strongly urges the application of the law of another state and it is not bound by seemingly conclusive precedent. In such matters as determining trustee's commissions the court would be particularly apt to apply its own rates and time of payment, especially since it might be argued that in applying to the court to have his account settled, the trustee

Bank v. Brewer, 27 Conn. 600 (1558); Spooner v. Phillips, 62 Conn. 62, 24 Atl. 524 (1592); Union \& New Haven Trust Company v. Watrous, 109 Conn. 268, 146 Atl. 727 (1929); Greenough v. Osgood, 235 Mass. 235, 126 N. E. 461 (1920); MI'Cullough's Ex's. v. M'Cullough, 44 N. J. Eq. 313, 14 Atl. 642 (Ch. 1S83); First National Banls of Paterson (N. J.) v. The National Broadway Bank in the City of New York, 156 N. Y. 459, 51 N. E. 398 (1898); Curtis v. Curtis, 185 App. Div. 391, 173 N. Y. Supp. 103 (1st Dep't, 1913); Squier v. Houghton, 131 Misc. 129, 226 N. Y. Supp. 162 (Sup. Ct. 1927); Lozier v. Lozier, 99 Ohio St. 254, 124 N. E. 167 (1919); Lanius v. Fletcher, 100 Texas 550, 101 S. W. 1076 (1907).

25. M'Cullough's Ex'rs. v. M'Cullough, 44 N. J. Eq. 313, 14 Atl. 642 (Ch. 189s); Spooner v. Phillips, 62 Conn. 62, 24 Atl. 524 (1S92); Farmers' and Mrechanics' Banls v. Brewer, 27 Conn. 600 (1858); First National Bank of Paterson (N. J.) v. The National Broadway Bank in the City of New York, 156 N. Y. 459, 51 N. E. 393 (1898); Curtis v. Curtis, 185 App. Div. 391, 173 N. Y. Supp. 103 (1st Dep't, 1918).

26. Suskin \& Berry v. Rumley, 37 F. (2d) 304 (C. C. A. 4th, 1930); Keency v. Morse, 71 App. Div. 104, 75 N. Y. Supp. 728 (1st Dep't, 1902); Curtis v. Curtis, 185 App. Div. 391, 173 N. Y. Supp. 103 (1st Dep't, 1918); Lozier v. Lozier, 99 Ohio St. 254, 124 N. E. 167 (1919); Lanius v. Fletcher, 100 Texas 550, 101 S. W. 1076 (1907).

27. In addition to express intention, the courts by "intention of the creator" sometimes mean an implied intent that the law of a certain jurisdiction should govern beeause many of the factual connections of the trust are in that jurisdiction. Mercer v. Buchan3n, 132 Fed. 501 (C. C. W. D. Pa. 1904). Intent is also sometimes used by the courts as the presumed intention that that law should govern, which will sustain the administration of the trust. Lanius v. Fletcher, 100 Texas 550, 101 S. W. 1076 (1907). An element of presumsd intent is also present in the interpretation of the language of the trust instrument. See cases in note 22.

28. Keeney v. Morse, 71 App. Div. 104, 75 N. Y. Supp. 728 (1st Dep't, 1902). Sse Lozier v. Lozier, 99 Ohio St. 254, 256, 124 N. E. 167, 167 (1919). 
waived his right to the rate of commission of another state, and that the time of payment was a matter of procedure to be governed by the forum.

Knowing the factors to which the courts have referred in determining the law governing administration of trusts of personalty, the problem is to determine the relative weights which the courts are likely to give them. When all the elements of the trust are found in one jurisdiction, it seems quite certain that regardless of where the action is brought the law of that jurisdiction will govern. ${ }^{29}$ Likewise where a preponderant number of the factors are grouped in one state, the decisions indicate that the group prevails over any single factor. Thus, where the trustee is in one state and the creator's domicil, place of probate or place of execution of the deed of trust, and location of the trust property are in another state, the courts hold that the law of the latter state governs the administration of the trust. ${ }^{30}$ The same result is found where the factor of domicil of the beneficiary, ${ }^{31}$ domicil of the creator, ${ }^{32}$ location of the trust res, ${ }^{33}$ or place of execution of the deed is in one state, ${ }^{84}$ and all or most of the remaining factors are in another state. The problem as to whether the factor of place of probate would govern, if it stood alone in one state, never arises, since it is never found to stand alone, the will always being probated either at the domicil of the testator or at the place

29. Codman v. Krell, 152 Mass. 214, 25 N. E. 90 (1890); In re Berry, 178 App. Div. 144, 164 N. Y. Supp. 990 (1st Dep't, 1917).

30. Matter of Avery, 45 Misc. 529, 92 N. Y. Supp. 974 (Sup. Ct. 1904); In re Fitzgerald (1904), 1 Ch. 573. See In re Berry, 178 App. Div. 144, 145, 164 N. Y. Supp. 990 (1st Dep't, 1917). A fortiori, where the trustee resided in the state of predominant factual connections at the time of the creation of the trust, but later moved to another jurisdiction, the law of the state of predominant factors is controlling. Ex Parte Moots, 217 III. App. 518 (1920) ; Swetland v. Swetland, 105 N. J. Eq. 608, 149 Atl. 50 (Ch. 1930).

31. Allen v. Tate, 6 F. (2d) 139 (C. C. A. 8th, 1925); Suskin \& Berry v. Rumley, 37 F. (2d) 304 (C. C. A. 4th, 1930); Merritt v. Corties, 24 N. Y. Supp. 561 (Sup. Ct. 1893) ; In re Havemeyer's Estate, 127 Misc. 197, 216 N. Y. Supp. 334 (Surr. Ct. 1926).

32. In the two cases found, one testamentary and the other an inter vivos transfer, in which, the domicil of the creator stood alone in one state, and the preponderance of tho remaining factors were in another state, the law of the latter state was held controlling in both instances. Lanius v. Fletcher, 100 Texas 550, 101 S. W. 1076 (1907); Greenough v. Osgood, 235 Mass. 235, 126 N. E. 461 (1920). In Russell v. Joys, 227 Mass. 263, 116 N. E. 549 (1917), and Tudor v. Vail, 195 Mass. 18, 80 N. E. 590 (1907), the settlors were domiciled in the place of predominant factual connections at the time the deeds of trust were executed, but subsequently moved, and the law of the place of predominant connections governed.

33. Farmers' and Mechanics' Bank v. Brewer, 27 Conn. 600 (1858); Spooner v. Phillips, 62 Conn. 62, 24 Atl. 524 (1892); Union \& New Haven Trust Company v. Watrous, 109 Conn. 268, 146 Atl. 727 (1929); Selleck v. Hawley, 331 Mo. 1038, 56 S. W. (2d) 387 (1932); Squier v. Houghton, 131 Misc. 129, 226 N. Y. Supp. 162 (Sup. Ct. 1927) ; First National Bank of Paterson (N. J.) v. The National Broadway Bank in the City of Now York, 156 N. Y. 459, 51 N. E. 398 (1898).

34. Swetland v. Swetland, 105 N. J. Eq. 608, 149 Atl. 50 (Ch. 1930). 
where the trust property is situated. No case was found in which the place in which the business of the trust was carried on stood alone. This is to be expected, since this factor would normally be coupled with the domicil of the trustee or location of the trust property.

In case there is more than one factor or element of the trust in each of two states, the court's decision as to what law should govern becomes more difficult. Since the facts of the particular cases differ, it may prove profitable to examine the facts of a few cases in order to illustrate the kind of situations with which the courts have been forced to deal and the weight given to various factors.

In one instance ${ }^{35}$ the indenture of trust had been executed in New Jersey and one of the two settlor-trustees was domiciled in New Jersey. The second settlor-trustee was domiciled in New York where the property was located; the beneficiary was there; and the trust was being administered in New York not only by the New York trustee but also by a trust company domiciled in New York which had been appointed successor trustee upon the death of the New Jersey trustee. The New York court stated that if both the settlor-trustees had resided in New Jersey, the law of New Jersey would have governed. Since this was not the case, however, the court applied the law of New York, specifically referring to the fact that the property, beneficiary, place of administration, and successor trustee were all in New York.

In another case involving an inter vivos trust, ${ }^{30}$ the settlor resided in New York at the time the deed of trust was executed in that state, and the securities were there delivered to the trustees. However all three trustees and the second life beneficiary who was suing for a Pennsylvania corporation stock dividend resided in Pennsylvania; and the settlor subsequently moved to that state. It was contended on behalf of the beneficiary that the settlor's moving to Pennsylvania and the fact that the trustees resided in Pennsylvania and would transact the business of the trust there made Pennsylvania law applicable. The federal court held, however, that the law of New York governed because the trust instrument was executed and delivered there and the settlor resided in New York at the time of the execution of the deed.

It was contended, in a case involving a testamentary trust, ${ }^{37}$ that since the trustees were residents of New York and were administering the trust property located in that state, the law of New York should govern. The court held, however, that the testatrix's having resided in Ohio, and the factor of probate of the will there, created an Ohio trust to be administered according to Ohio law unless an intention could be inferred that the testatrix desired the law of some other state to govern. And it was thought such an intention could not be inferred from the

35. Curtis v. Curtis, 185 App. Div. 391, 173 N. Y. Supp. 103 (1st Dep't, 1918).

36. Mercer v. Buchanan, 132 Fed. 501 (C. C. W. D. Pa. 1904).

37. Lozier v. Lozier, 99 Ohio St. 254, 124 N. E. 167 (1919). 
fact that the domicil of the trustee, the location of the property and the administration of the trust were in New York.

In another case ${ }^{38}$ it was argued that the fact that the testator named a trustee who, at the time the will was made, as well as at the time of the testator's death, was a resident of New Jersey, showed that the testator intended the trust to be administered in accordance with the laws of New Jersey. Here there had also been an ancillary probate proceeding in New Jersey and presumably the trustee kept the property at his domicil in New Jersey, but the New Jersey court held that the law of Pennsylvania, the testator's domicil and place of original probate, governed the administration of the trust. The court was not informed where the beneficiary was domiciled but stated that even if both the beneficiary and trustee were domiciled in New Jersey at the dates mentioned, still the law of Pennsylvania would govern..$^{30}$

In one case, however, the law of the testator's domicil and place of probate in Rhode Island was held not to govern as against a preponderance of the remaining elements of the trust in New York. ${ }^{40}$ Here, not only were the trustee, trust property and place of administration in New York, but creditors of the beneficiary had obtained a judgment against him in New York and were attempting to enforce the judgment against the trustee. The New York court in this case applied its local law. The decision may perhaps be explained as an illustration of the principle that every state has jurisdiction to determine for itself the liability of property within its territorial limits to seizure and sale under the process of its courts, ${ }^{41}$ but that is not the basis of the court's opinion.

In many of the cases the courts based their opinion on an inference of intention from the statements of the creator of the trust that the law of a certain jurisdiction should govern the administration of the trust. In determining intent, however, these courts have considered the same factors as other courts which did not mention intent, and have therefore achieved the same results.

No court has listed in the order of their importance the several factors of a trust which it considers in determining the governing law. It is therefore necessary in evaluating the relative importance of the various elements of a trust to be guided by the actual holdings of cases and the references made by the courts to the different factors. In both testamentary and inter vivos trusts the domicil of the beneficiary does not seem to be given a great deal of weight by the courts. Since the bene-

38. Rosenbaum v. Garrett, 57 N. J. Eq. 186, 41 Atl. 252 (Ch. 1898). .

39. Similarly a combination of factors consisting of the domicil of the testator, probate of the will, and domicil of one of the beneficiaries was held to prevail over the domicil of the trustee, location of the property, and place of administration. M'Cullough's Ex'rs. v. M'Cullough, 44 N. J. Eq. 313, 14 Atl. 642 (Ch. 1888).

40. Keeney v. Morse, 71 App. Div. 104, 75 N. Y. Supp. 728 (1st Dep't, 1902).

41. Clark v. Williard, 294 U. S. 211 (1935). 
ficiaries of a trust are apt to be scattered in several jurisdictions and ordinarily do not play an important role in its administration, it seems quite proper that this factor should not be considered important. In testamentary trusts the domicil of the testator and place of probate of the will are accorded particular significance. In fact, in every testamentary trust case, except one, ${ }^{42}$ a combination of the domicil of the testator and probate of the will in one state, whether or not additional factors were present, caused the law of that state to govern. The remaining factors in a testamentary trust seem to be given approximately equal consideration with each other. In trusts inter vivos the elements upon which the courts seem to lay most stress are the domicil of the creator, domicil of the trustee, place of execution of the indenture of trust, and location of the trust property.

In answer to the question whether a distinction is made by the courts as between the various problems of administration of a trust, it would appear that all the problems are treated similarly except in the case of trustee actions for commissions and in actions by the beneficiary to terminate the trust. ${ }^{43}$ In cases relating to trustee's commissions, it would seem that the court before whom the trustee accounts determines the amount of his commissions and in doing so pould have a tendency to apply its local rates and applicable rules. ${ }^{14}$ If this is true, then in testamentary trusts, since the accounting proceedings are usually brought at the place of probate of the will, the law of that jurisdiction will ordinarily control. In the event that a court other than the probate court assumes jurisdiction over the accounting proceeding, it is possible that it will apply its own law regarding commissions on the theory that the question is one of procedure rather than substantive right and that the trustee waived his right to the rates prevailing in some other state by failing to account there. ${ }^{45}$ In actions brought by the beneficiary to terminate a trust and obtain the corpus, the courts, on the theory of an implied intent on the part of the creator to have the trust carried out, seem to endeavor to apply the law of that state which will sustain the trust. ${ }^{46}$

42. Keeney v. Morse. 71 App. Div. 104, 75 N. Y. Supp. 725 (1st Dep't, 1902).

43. In proceedings to remove a trustee the question of conflict of laws ssems to play a relatively unimportant rôle. For, under the laws of practically every state, a trustee vill be removed if he has misappropriated the trust assets or has otherwise misconducted himself. Whitney v. Dodge, $105 \mathrm{Cal} .192,38$ Pac. 636 (1894); Jones v. Jones, 8 Misc. 660 , 30 N. Y. Supp. 177 (Sup. Ct. 1894).

44. Ex Parte Moots, 217 IIl. App. 518 (1920).

45. The fact that in many states the amount of commissions to be awarded truetees is determined by the court in the exercise of its discretion, supports the position that this particular problem of administration is more apt to be controlled by the lan of the forum than are other administrative questions.

46. Lanius v. Fletcher, 100 Tesas 550, 101 S. W. 1076 (1907). See Rosenbzum v. Garrett, 57 N. J. Eq. 186, 194, 41 Atl. 252, 255 (Ch. 1898). 
In some cases the elements of the trust have shifted between the time of the creation of the trust and the bringing of the action so that it is necessary to determine whether these shifts affect the governing law. A variety of changes in the factual connections of the trust are possible: donors, trustees and beneficiaries may change their domicil, and the trust property and place of administration of the trust often move with the trustee. In two cases the trust assets were removed to or invested in another state after the creation of the trust, but the court in ench case indicated that it. was the location of the property at the time of the creation of the trust which was important. ${ }^{47}$ It has likewise been held that a change of domicil by the settlor of the trust ${ }^{48}$ or by the beneficiary ${ }^{40}$ after the execution of the deed of trust had no effect upon what law governed the administration of the trust. Some of the cases do indicate, however, that a change in the domicil of the trustee or the selection of a successor trustee domiciled in another state is important..$^{50}$ The fact that ordinarily the place at which the business of the trust is conducted is at the domicil of the trustee lends added importance to such a change of domicil of the trustee. It would seem that the courts following the intent theory would determine the governing law as of the time the gift was created, unless an intent on the part of the testator to have the governing law shift with the other factors is found. Courts ignoring the intent point of view could easily take either date as determinative since their standard is arbitrary in the first place.

\section{CONCLUSION}

In the light of the foregoing discussion, the rules formulated by the American Law Institute may be reexamined. As to the rule for testamentary trusts that the law of the testator's domicil governs unless a

47. Matter of Avery, 45 Misc. 529, 92 N: Y. Supp. 974 (Sup. Ct. 1904); Farmers' and Mechanics' Bank v. Brewer, 27 Conn. 600 (1858).

48. Mercer v. Buchanan, 132 Fed. 501 (C. C. W. D. Pa. 1904); Tudor v. Vail, 195 Mass. 18, 80 N. E. 590 (1907); Russell v. Joys, 227 Mass. 263, 116 N. E. 549 (1917); In re Fitzgerald (1904) $1 \mathrm{Ch}$. 573. In testamentary trust cases it is, of course, the domicil of the testator at the time of his death and not his residence when the will was executed which is important in determining what law governs the administration of the trust, although under some statutes the law of the domicil of the testator at the execution of the will is important in regard to the validity of the will.

49. Mercer v. Buchanan, 132 Fed. 501 (C. C. W. D. Pa. 1904); Codman v. Krell, 152 Mass. 214,25 N. E. 90 (1890).

50. In re Berry, 178 App. Div. 144, 164 N. Y. Supp. 990 (1st Dep't, 1917) ; First National Bank of Paterson (N. J.) v. The National Broadway Bank in the City of New York, 156 N. Y. 459, 51 N. E. 398 (1898) ; Curtis v. Curtis, 185 App. Div. 391, 173 N. Y. Supp. 103 (1st Dep't, 1918). In Farmers' and Mechanies' Bank v. Brewer, 27 Conn. 600 (1858), the court referred to the fact that the trustee had remained in Massachusetts. In Swetland v. Swetland, 105 N. J. Eq. 608, 149 Atl. 50 (Ch. 1930), however, the court in a living trust referred to both the domicil of the trustee, and of the successor trustees on the date of the execution of the deed. 
trust company of another state has been appointed trustee, in which case the law of the trustee's domicil governs, it was found that when the testator's domicil stood alone in one state and a preponderance of the remaining factual connections were in another state the law of this latter state governed. ${ }^{51}$ It was also found that where a trust company of state $\mathbf{X}$ was appointed trustee and a preponderance of the remaining factors were in state $Y$, the law of $Y$ was held to govern the administration of the trust. ${ }^{52}$ Therefore, what meager authority there is seems to be contrary to the view of the American Law Institute. Instead of relying upon any single element for determining the governing law, the courts in testamentary, as well as in inter vivos trusts, seem to depend upon a group of factors. In connection with inter vivos trusts it was found that two of the more important factors which the courts look to in determining what law governs, namely the domicil of the creator and place of execution of the deed of trust, both of which relate to the creation of the trust rather than to its administration, are given no consideration by the American Law Institute rule. The problem of evaluating the importance of the several elements of the trust is omitted in the Restatement rules. The cases indicate, however, that a difference does exist. Thus, just as the factors of domicil of the testator at time of death and place of probate of the will, particularly when combined in one state, are of primary importance in the case of testamentary trusts, in the case of inter vivos trusts, the domicil of the creator of the trust, domicil of the trustee, place of execution of the indenture of trust, and location of the trust property, seem to be most stressed by the courts. In both testamentary and inter vivos trust cases the domicil of the beneficiary is accorded slight importance. Furthermore, no mention is made in the rules of the American Law Institute as to whether shifts in the factual connections between the time of creation of the trust and the bringing of the action are important, although in a number of cases the change in domicil of the trustee or the appointment of a successor trustee in another state was alluded to by the court. Since the place of administration of the trust may well shift with the trustee, this is a matter of no small importance. Again, nothing is said as to whether a distinction needs to be made between the various problems of trust administration in determining what law governs, although, at least as to trustee's commiscions and in actions by the beneficiary to terminate the trust, special considerations apply.

Mav the attorney avoid the possible necessity for a judicial determina. tion of what law governs when the elements of the trust are scattered in two or more states merely by inserting a provision in the trust instrument that the law of a particular jurisdiction shall govern the adminis-

51. Lanius v. Fletcher, 100 Texas 550, 101 S. W. 1076 (1907).

52. Matter of Avery, 45 Misc. 529, 92 N. Y. Supp. 974 (Sup. Ct. 1904). 
tration of the trust? ${ }^{53}$ From the decided cases it would seem that if a will creating a trust states that the law of a particular jurisdiction shall govern the investment and management of the trust, and the testator and trustee ${ }^{54}$ or the trustee ${ }^{55}$ is domiciled in the state selected, the law of that state undoubtedly will be applied. Similarly, an inter vivos trust has been held to be governed by the law of the creator's domicil because he so provided, despite the trustee's residence in another jurisdiction. $^{56}$ In New York it is provided by statute that the express intent of the creator to have the New York law govern the creation and administration of the trust shall be enforced if the personal property is situated within New York at the time the trust was created or if the trustee resides in New York. ${ }^{57}$ If, however, the state designated has no substantial connection with the trust, it is not known what the courts will do. The position might well be maintained that, since the settlor clearly could provide in the trust instrument the amount of the trustee's commissions, the type of investments which the trustee should make, and the allocation of dividends to be made between income and principal, he should be able to control such administrative matters by reference to the law of a particular state, whether or not the trust has any other connection with that state. An exception, however, should be noted in the case of problems of administration controlled by rules of law involving a strong element of public policy, since the court of the forum might refuse to follow the foreign law in such an instance. ${ }^{68}$

53. For a discussion of the effect given to the expressed intention of the parties in contract law, see Beale, What Law Governs Validity of a Contract (1910) 23 HARv. L. REv. 260.

54. Matter of Norton, 129 Misc. 875, 224 N. Y. Supp. 77 (Surr. Ct. 1927). In Lozier v. Lozier, 99 Ohio St. 254, 124 N. E. 167 (1919) the court stated that if the testatrix had expressed an intention as to what law should govern, this intention would have been followed, although there was no indication as to whether the testatrix's choice of juridictions was unrestricted.

55. Macy v. Mercantile Trust Co., 68 N. J. Eq. 235, 59 Atl. 586 (Ch. 1904).

56. Liberty National Bank \& Trust Co. in New York v. New England Investors Shares, Inc., 25 F. (2d) 493 (D. Mass. 1928).

57. N. Y. Pers. Prop. Law (Supp. 1935) 25, \& 12a.

58. For example, the creator of a New York trust may have provided for allocations to be made between income and corpus which would be invalid in New York as constituting an unlawful accumulation but be perfectly valid under the laws of New Jersey. It is not at all clear that the settlor has the power to validate such a provision in the trust merely by providing that New Jersey law should govern the validity and administration of the trust.

In connection with the administration problem of the alienability of a beneficiary's interest, a provision that the cestui's interest should not be alienable or subject to the clalms of creditors also raises the question whether a creator could validate this term of the trust by providing that the law of another state should govern.

Certainly as to questions relating entirely to the validity of a trust, as the rule against perpetuities, a creator cannot provide that the more liberal rule of another state which 
As to most administration problems, however, the express intention of the settlor will control, particularly since the settlor would generally not select a state completely separate from the incidents of the trust. Therefore a practical solution to this whole question, which is really one of avoiding litigation on the issue, would be for the draftsman to insert a clause in the trust instrument which would provide what law should govern. The following phraseology is used by one of the law offices in New York City to express the testator's intent that the law of New York govern:

"I hereby direct in accordance with Section 47 of the Decedent's Estate Law of the State of New York that the validity and effect of the testamentary dispositions made by me herein shall be determined by the Laws of said State of New York."

has no connection with the trust shall govern. City Bank Farmers Trust Co. v. Check, 93 N. Y. L. J. 2941, June 7, 1935. 